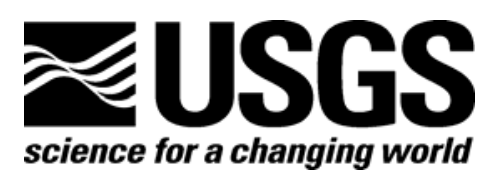

\title{
Development of a Land Use Database for the Little Blackwater Watershed, Dorchester County, Maryland
}

By Lesley E. Milheim, John W. Jones, and Roger A. Barlow

Open-File Report 2007-1309

U.S. Department of the Interior

U.S. Geological Survey 


\title{
U.S. Department of the Interior DIRK KEMPTHORNE, Secretary
}

\author{
U.S. Geological Survey \\ Mark D. Myers, Director
}

U.S. Geological Survey, Reston, Virginia 2007

For product and ordering information:

World Wide Web: http://www.usgs.gov/pubprod

Telephone: 1-888-ASK-USGS

For more information on the USGS - the Federal source for science about the Earth, its natural and living resources, natural hazards, and the environment:

World Wide Web: http://www.usgs.gov

Telephone: 1-888-ASK-USGS

Suggested citation:

Milheim, L.E., Jones, J.W., and Barlow, R.A., 2007, Development of a land use database for the Little Blackwater River watershed, Dorchester County, Maryland: U.S. Geological Survey Open-File Report 20071309, 12 p., available online at http://pubs.usgs.gov/of/2007/1309/.

Any use of trade, product, or firm names is for descriptive purposes only and does not imply endorsement by the U.S. Government.

Although this report is in the public domain, permission must be secured from the individual copyright owners to reproduce any copyrighted material contained within this report. 


\section{Contents}

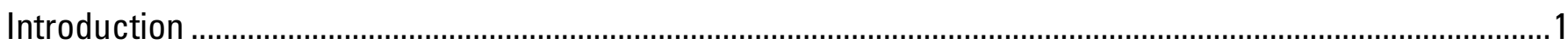

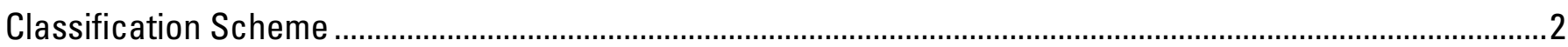

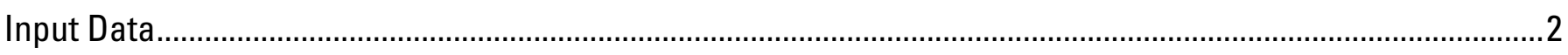

National Agricultural Imagery Program Dataset for Dorchester County, Maryland.........................................2

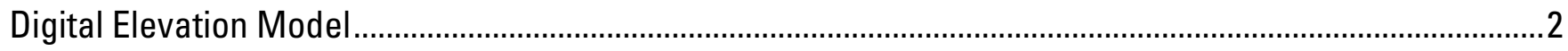

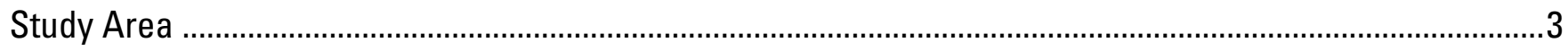

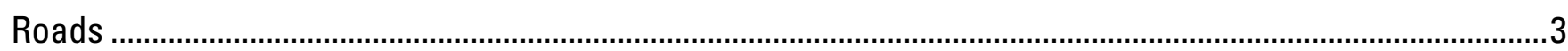

Streams

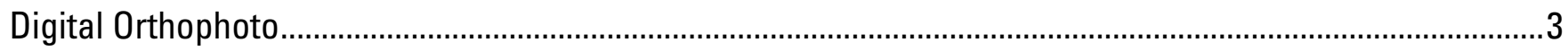

Software

Processing Steps

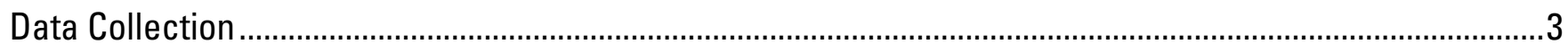

Quality Assurance/Quality Control .....................................................................................................

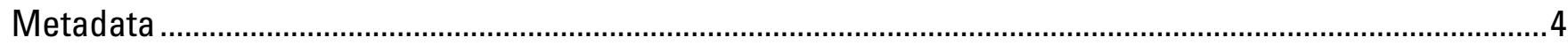

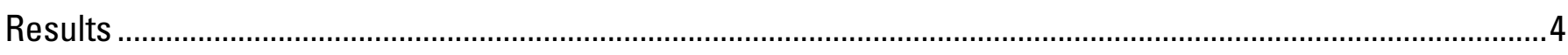

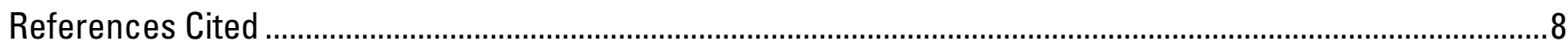

\section{Figures}

Figure 1. Lidar-based digital elevation model (DEM) of the Little Blackwater River watershed study area (44.5 square kilometers). Study area delineated by a red line (main map and index map). Watershed boundary includes a 100-meter buffer. Egypt Road project delineated by an orange line. Stream gage location identified by a blue dot. 
Figure 2. Land use polygon boundaries (black lines) within the Little Blackwater River watershed study area overlain on National Agricultural Imagery Program (NAIP) orthoimagery of June-July 2005. Study area delineated by red line.

Figure 3. Classified land use polygons within the Little Blackwater River watershed study area overlain on National Agricultural Imagery Program (NAIP) orthoimagery of June-July 2005

\section{Tables}

Table 1. Summary of land use within the Little Blackwater River watershed, June-July 2005. .4 


\title{
Development of a Land Use Database for the Little Blackwater River Watershed, Dorchester County, Maryland
}

\author{
By Lesley E. Milheim, John W. Jones, and Roger A. Barlow
}

\section{Introduction}

Many agricultural and forested areas in proximity to National Wildlife Refuges (NWR) are under increasing economic pressure to develop lands for commercial or residential development. The upper portion of the Little Blackwater River watershed - a 27 square mile area within largely low-lying Dorchester County, Maryland, on the eastern shore of the Chesapeake Bay - is important to the U.S. Fish and Wildlife Service (USFWS) because it flows toward the Blackwater National Wildlife Refuge (BNWR), and developmental impacts of areas upstream from the BNWR are unknown.

One of the primary concerns for the refuge is how storm-water runoff may affect living resources downstream. The Egypt Road project (fig. 1), for which approximately 600 residential units have been approved, has the potential to markedly change the land use and land cover on the west bank of the Little Blackwater River. In an effort to limit anticipated impacts, the Maryland Department of Natural Resources (Maryland DNR) recently decided to purchase some of the lands previously slated for development. Local topography, a high water table (typically 1 foot or less below the land surface), and hydric soils present a challenge for the best management of storm-water flow from developed surfaces.

A spatial data coordination group was formed by the Dorchester County Soil and Conservation District to collect data to aid decisionmakers in watershed management and on the possible impacts of development on this watershed. Determination of streamflow combined with land cover and impervious-surface baselines will allow linking of hydrologic and geologic factors that influence the land surface. This baseline information will help planners, refuge managers, and developers discuss issues and formulate best management practices to mitigate development impacts on the refuge.

In consultation with the Eastern Region Geospatial Information Office, the dataset selected to be that baseline land cover source was the June-July 2005 National Agricultural Imagery Program (NAIP) 1-meter resolution orthoimagery of Maryland. This publicly available, statewide dataset provided imagery corresponding to the closest in time to the installation of a U.S. Geological Survey (USGS) Water Resources Discipline gaging station on the Little Blackwater River. It also captures land cover status just before major residential development occurs. This document describes the process used to create a land use database for the Little Blackwater watershed. 


\section{Classification Scheme}

The first step in any land use mapping effort is the design of a land use classification and mapping scheme that is appropriate for the intended use of the data. The USGS and Maryland DNR discussed classification requirements on August 10, 2006, at the Maryland Department of Natural Resources in Annapolis. After consultation the Dorchester County Soil and Conservation Service, the group decided to use a modified Anderson Level I (Anderson, 1972) tailored to the major classes of land use and land cover observed in the watershed. Use of an Anderson Level II classification was viewed as ineffective in terms of time and usefulness. Classes used for this study include:

Commercial - includes churches, schools, and governmental, construction, and manufacturing, grounds (non-residential), buildings and parking lots,

Transportation - primarily based on Maryland State Highway Administration road centerline shapefile as well as roads associated with new construction, railroad bed, and the airport grounds,

Residential - residential neighborhoods and grounds including farmhouses if they were distinct from farm buildings,

Agricultural - crop fields, chicken houses, barns, equipment, and other storage buildings and associated grounds,

Open area - areas that are not associated with other uses and may be subject to developmental pressure,

Forest - predominance of forested land. In this area, much of the forest is wet because of the low elevation and gradient. The forest class also includes relatively open areas where there was evidence of clearing and new forest growth. The area has a history of cyclic forest clearance,

Water - open water in wetlands, forests, agricultural areas, and stormwater mitigation ponds. Ponds are scattered throughout the watershed where farmers have allowed water to pond so that other areas may be cultivable and are often smaller than the stated minimum area of 0.25 acre (criteria established at the August 10, 2006, meeting). However, the frequency of occurrence provides an indication of the general wetness within this watershed and, therefore, they were mapped,

Wetland - wet forest along drainage areas that may include limited marsh. The distinction between this classification and forest is very subjective,

Disturbed area - areas prepared for construction and actual construction sites.

\section{Input Data} used.

To map land use according to the classification scheme specified, the following input data were

\section{National Agricultural Imagery Program Dataset for Dorchester County, Maryland}

This June-July 2005 1-meter resolution agricultural (leaf-on) imagery (NAIP_Dorchester.sid) shown in figure 2 was used to visually identify land use and land cover within the Little Blackwater River watershed (http://dnrweb.dnr.state.md.us/gis/data/data.asp).

\section{Digital Elevation Model}

An ArcGRID containing the 2-meter resolution Lidar digital elevation model (DEM) (abovebnwr) for a subset of Dorchester County, Maryland (Figure 1.) was used to identify the watershed boundary. This dataset is the mosaic of the Lidar DEM subsets available from the Maryland Department of Natural Resources. The Lidar subsets used are: ab1331, ab1332, ab1333, ab1334, ab1335, ab1336, aa1331, aa1332, aa1333, aa1334,aa1335, aa1336, z1331, z1332, z1333, z1334, ab1341, ab1342, 
ab1343, ab1344, ab1345, ab1346, aa1341, aa1342, aa1343, aa1344, aa1345, aa1346, z1341, z1342, z1343, z1344, ab1351, ab1352, ab1353, ab1354, ab1355, ab1356, aa1351, aa1352, aa1353, aa1354, aa1355, aa1356, z1351, z1352, z1353, z1354, ab1361, ab1363, ab1365, aa1361, aa1363, aa1365, z1361, and z1363.

\section{Study Area}

These data (BufferedStudyArea.shp) identify the watershed boundary plus a 100-meter buffer (fig. 1.) for the Little Blackwater River. The file was generated from the digital elevation model above the USGS stream gage located approximately 1.5 miles downstream of the confluence of the Maple Dam Branch and the Little Blackwater River (lat. 38 30'06" N, long. 76 05'39" W) using the ArcMap 9.0 Spatial Analyst Hydrology toolkit. It resembles earlier watershed boundaries for this area excluding the area east of the airport.

\section{Roads}

These data (SHA_cline_SA.shp) identify the center-lines for roads within the watershed. The original shapefile is available from the Maryland State Highway Administration website (http://www.marylandgis.net/SHAdata/list.asp) and was trimmed to the study area.

\section{Streams}

These data (SHA_streams_SA.shp) identify the streams within the watershed. The original shapefile is available from the Maryland State Highway Administration website (http://www.marylandgis.net/SHAdata/list.asp) and was trimmed to the study area.

\section{Digital Orthophoto}

These 4-meter resolution digital orthophotos (Cambr215.tif, Cambr315.tif, 1998) available from the Maryland Department of Natural Resources website (http://dnrweb.dnr.state.md.us/gis/data/data.asp), were used as ancillary data for interpretation.

\section{Software}

The following software packages were used to create the database.

- Platform: Windows XP

- Environmental Systems Research Institute (ESRI) ArcGIS Desktop 9.0 with Spatial Analyst Extension

- Habitat Digitizer Extension Version 4 Created by Ken Buja (Ken.Buja@ noaa.gov) of the National Oceanographic and Atmospheric Administration (http://ccma.nos.noaa.gov/products/biogeography/digitizer/index.html)

\section{Processing Steps}

\section{Data Collection}

ArcMap 9.0 was used to collect the land use and land cover areas within study area from the agricultural imagery (NAIP_Dorchester.sid). Compilation was performed using the ArcMap editor and the Habitat Digitizer Extension. Each area was visually identified by linear patterns, texture, and color and digitized along the perceived visual boundary. Visual interpretation was performed within ArcMap at a scale of 1:1500 and at a screen resolution of $1280 \times 1024$ pixels. As each area was completed, it was classified with a unique numeric identifier (UNIQUE_ID) and a description. Additional comments were entered to clarify or question the assigned classification as needed. Areas under question were visited to 
ascertain the validity of the assigned class and update the record, as needed. Boundaries were clipped to the study area to create the final land use/land cover shapefile. The polygon areas were calculated and added to the attribute table.

\section{Quality Assurance/Quality Control}

Due to time and funding constraints, no formal statistical or sampling quality assurance/quality control measures were performed. Instead, the classified polygons were compared with the actual land use and land cover observed through an onsite visit in October 2006 to confirm the identified classes and evaluate questionable classifications. This comparison resulted in the updating of some polygon attributes to provide a greater consistency in the final set of classes. Recent development in the area precluded the confirmation of some sites interpreted as undeveloped land cover types, given the date of the source imagery.

\section{Metadata}

Metadata were generated using ArcCatalog and the Federal Geographic Data Committee (FGDC) ESRI template and are available as part of the shapefile contents.

\section{Results}

The process resulted in a shapefile (LBRW_LULC.shp) containing the land use/land cover for the Little Blackwater River watershed as depicted in the June-July 2005 agricultural imagery shown in figure 1 . The land use polygons are shown unclassified in figure 2 over the agricultural imagery (NAIP_Dorchester.sid) and are shown as classified in figure 3. The summary of these results is shown in table 1.

Table 1. Summary of land use within the Little Blackwater River watershed, June-July 2005.

[Abbreviations: $\mathrm{m}^{2}$, square meters; $\mathrm{km}^{2}$, square kilometers]

\begin{tabular}{llllc}
\hline UNIQUE_ID & \multicolumn{1}{c}{ CLASSIFICATION } & $\begin{array}{c}\text { COUNT OF } \\
\text { POLYGONS }\end{array}$ & AREA $\left(\mathbf{k m}^{2}\right)$ & $\begin{array}{c}\text { PERCENT OF STUDY } \\
\text { AREA }\end{array}$ \\
\hline 1 & Commercial & 49 & 1.3 & 3.0 \\
2 & Transportation & 25 & 1.1 & 2.4 \\
3 & Residential & 127 & 1.6 & 3.5 \\
4 & Agricultural & 305 & 18.9 & 42.6 \\
5 & Open area & 107 & 2.5 & 5.7 \\
6 & Forest & 97 & 16.0 & 35.9 \\
7 & Water & 52 & 0.3 & 0.6 \\
8 & Wetland & 75 & 2.5 & 5.6 \\
9 & Disturbed area & 13 & 0.3 & 0.7 \\
& Total & & 44.5 & 100.0 \\
\hline
\end{tabular}




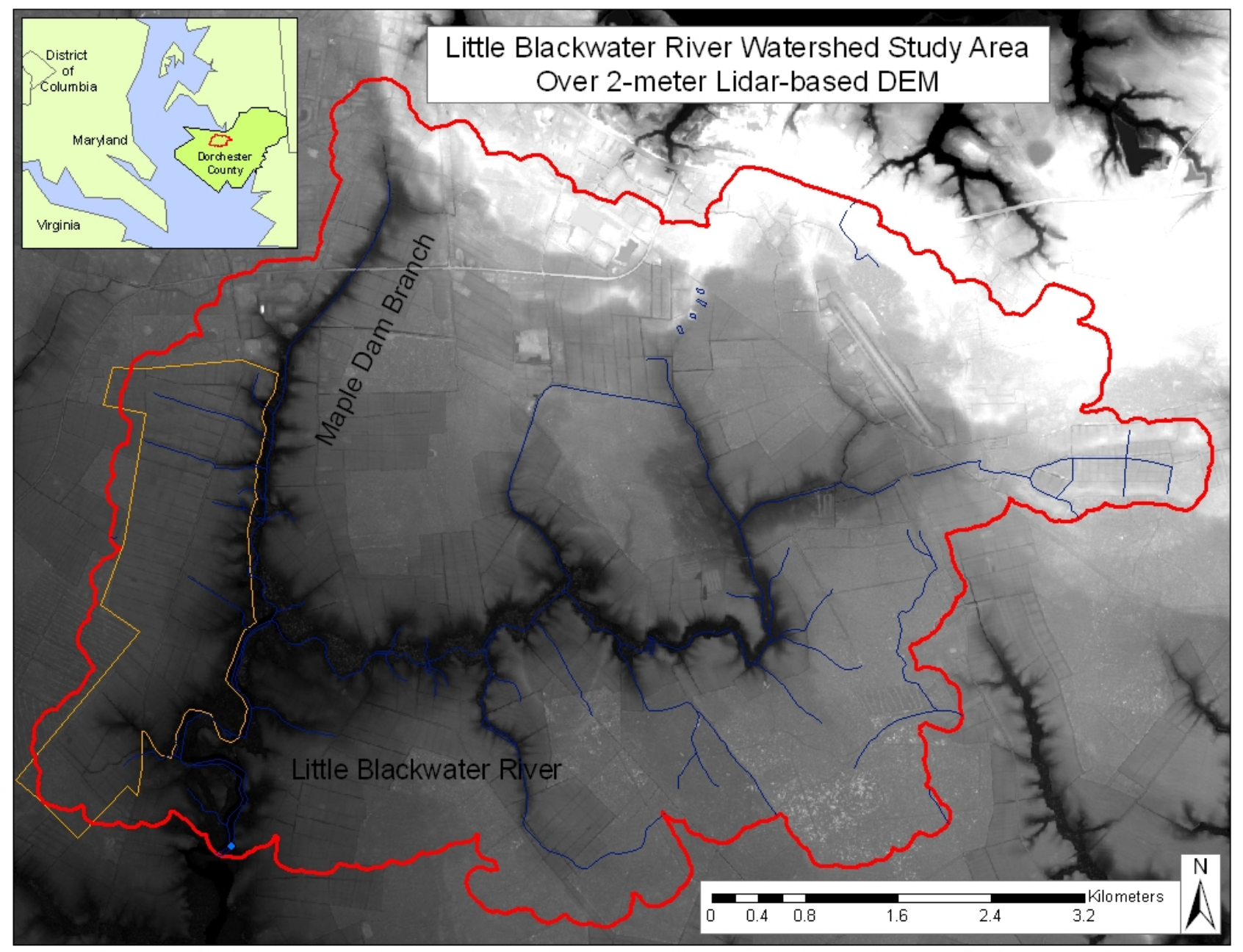

Figure 1. Lidar-based digital elevation model (DEM) of the Little Blackwater River watershed study area (44.5 square kilometers). Study area delineated by a red line (main map and index map). Watershed boundary includes a 100-meter buffer. Egypt Road project delineated by an orange line. Stream gage location identified by a blue dot. 


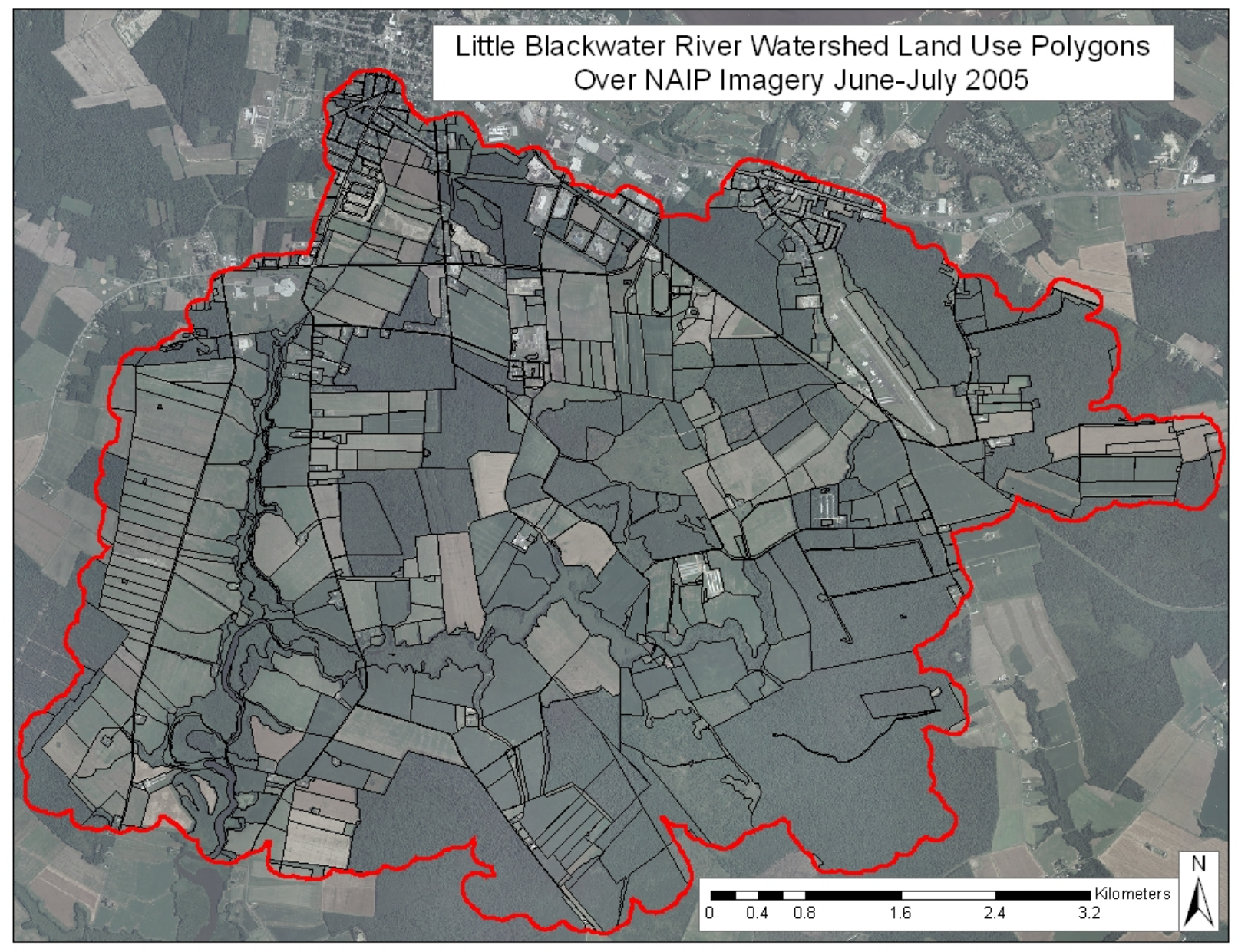

Figure 2. Land use polygon boundaries (black lines) within the Little Blackwater River watershed study area overlain on National Agricultural Imagery Program (NAIP) orthoimagery of June-July 2005. Study area delineated by red line. 


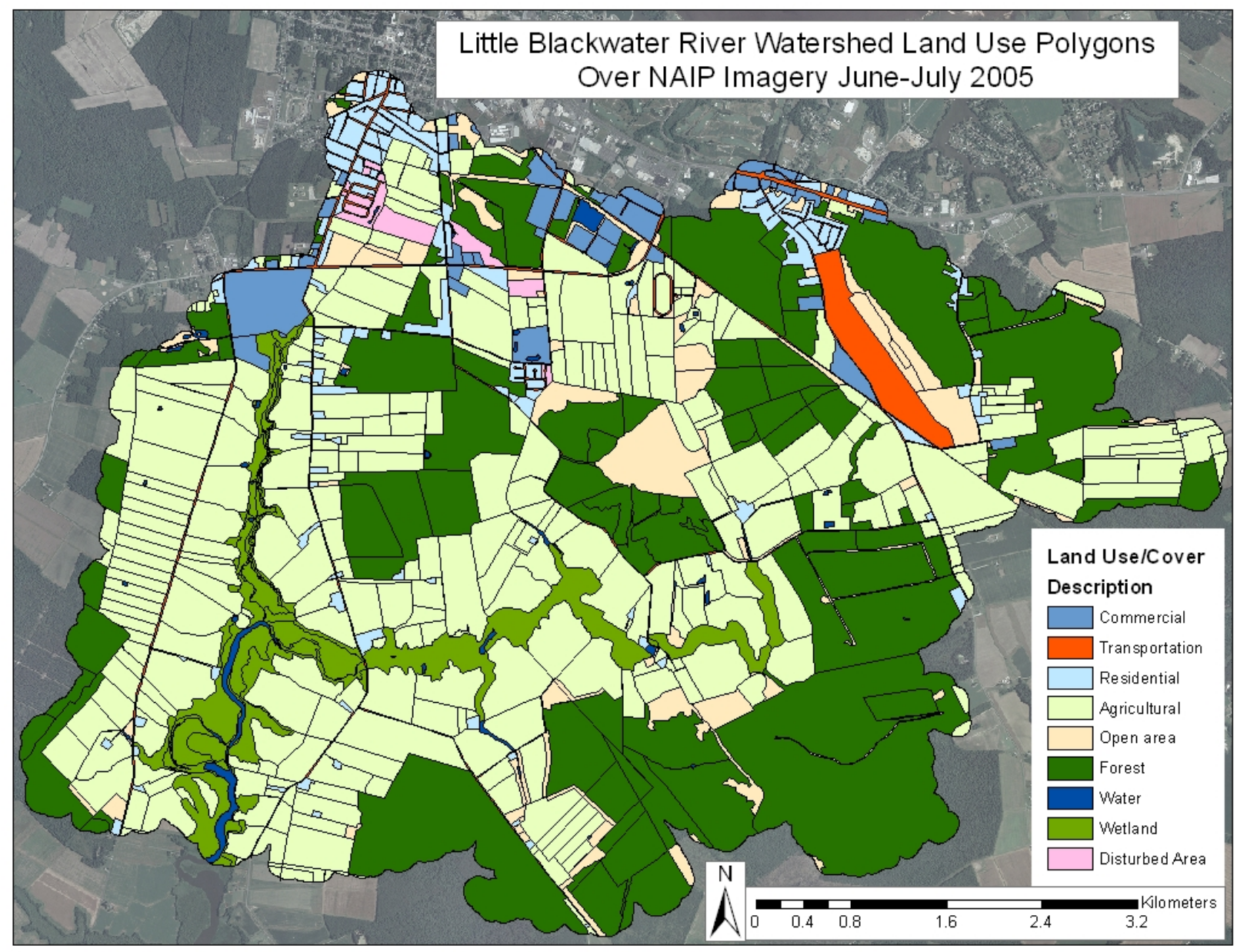

Figure 3. Classified land use polygons within the Little Blackwater River watershed study area overlain on National Agricultural Imagery Program (NAIP) orthoimagery of June-July 2005. 


\section{References Cited}

Anderson, J.R., Hardy, E.E., and Roach, J.T., 1972, A land-use classification system for use with remote-sensor data: U.S. Geological Survey Circular 671, 16 p. 